\title{
ОСНОВНІ ЕТАПИ ОЦІНЮВАННЯ МОВНОЇ КОМПЕТЕНЦІЇ СТУДЕНТІВ-ІНОЗЕМЦІВ 4-Х КУРСІВ ТЕХНІЧНИХ ВИШІВ 3 УКРАЇНСЬКОЇ МОВИ ЯК ІНОЗЕМНОЇ
}

\author{
Бойко Г. I. \\ викладач кафедри іноземних мов \\ Начіональний університет «Львівська політехніка» \\ вул. Степана Бандери, 12, Львів, Україна \\ orcid.org/000-0002-03866-5478 \\ GalBojko@gmail.com
}

\begin{abstract}
Ключові слова:
сертифікаційні тестування, стандартизовані вимоги, кваліфікаційний іспит, види мовленнєвої діяльності, українська мова як іноземна.
\end{abstract}

\begin{abstract}
У статті висвітлено основні етапи оцінювання мовної компетенції студентів-іноземців 4-х курсів технічних вишів 3 української мови як іноземної (УМІ). Зосереджено увагу на важливих проблемах організації проведення кваліфікаційних тестувань за всіма видами мовленнєвої діяльності, такими як слухання, письмо, читання і говоріння. Акцентовано увагу на чіткості і послідовності методики щодо кваліфікаційного іспиту 3 УМІ у НУ «Львівська політехніка», застосуванні та використанні посібника «Стандартизовані вимоги: рівні володіння українською мовою як іноземною А1-С2. Зразки сертифікаційних завдань, 2020». Посібник містить чіткий перелік комунікативних умінь і навичок до кожного рівня, а також у ньому наведені зразки сертифікаційних завдань, які стануть у нагоді викладачам української мови як іноземної, працівникам центрів україністики, іноземним громадянам, які мають намір підтвердити свій рівень володіння УМІ під час сертифікаційного іспиту. Стандартизовані вимоги є першим кроком до створення єдиної державної уніфікованої системи визначення рівнів володіння українською мовою. Запровадження в Україні Стандартизованих вимог з УМІ дає викладачам у цілому світі міцне підгрунтя, щоб розробляти чіткі й узгодженні навчальні програми, видавати сучасні підручники i словники, відкривати україномовні програми та мовні центри. Під час проведення кваліфікаційного іспиту викладачі кафедри іноземних мов оріснтуються на рівень С1 (високий) у випускників-іноземців НУ «Львівська політехніка», тому чітко слідують структурі проведення сертифікаційної роботи зі Стандартизованих вимог: читання (30 хв, 4 завдання), письмо (75 хв, 2 завдання), слухання (15 хв, 3 завдання), говоріння (15 хв, 2 завдання). Оцінювання: за кожну правильну відповідь - один бал.

У статті наголошено, що стандартизовані вимоги до рівнів володіння українською мовою як іноземною - це стратегічний документ і для освітньої політики, і для мовної політики, і для міжнародної політики України, який посилює престиж української мови у світі.
\end{abstract}




\title{
MAIN STAGES OF ASSESSMENT OF LANGUAGE COMPETENCE OF FOREIGN STUDENTS 4 COURSES OF TECHNICAL EMBROIDERIES WITH UKRAINIAN LANGUAGE AS FOREIGN
}

\author{
Boyko G. I. \\ Lecturer at the Department of Foreign Languages \\ Lviv Polytechnic National University \\ Stepana Bandery str., 12, Lviv, Ukraine \\ orcid.org/000-0002-03866-5478 \\ GalBojko@gmail.com
}

Key words: certification testing,
standardized requirements,
qualification exam, types of
speech activity, Ukrainian
language as a foreign language.

\begin{abstract}
The article highlights the main stages of assessing the language competence of foreign students 4 courses of technical universities in Ukrainian as a foreign language (UFL). Attention is focused on the important problems of organizing qualifying tests for all types of speech activities: listening, writing, reading and speaking. The focus is on the clarity and consistency of the methodology for the qualifying exam in UFL at Lviv Polytechnic National University. Application and use of the manual «Standardized requirements: levels of proficiency in Ukrainian as a foreign language A1-C2. Samples of certification tasks, 2020». The manual contains a clear list of communication skills and abilities for each level, as well as examples of certification tasks that will be useful for teachers of Ukrainian as a foreign language, employees of Ukrainian studies centers, foreign citizens who intend to confirm their level of UFL during the certification exam. Standardized requirements are the first step towards creating a single state unified system for determining the levels of proficiency in the Ukrainian language. The introduction of Standardized Media Requirements in Ukraine provides teachers around the world with a solid foundation to develop clear and consistent curricula, to publish modern textbooks and dictionaries, and to open Ukrainian-language programs and language centers. When conducting the qualifying exam, teachers of the Department of Foreign Languages focus on the level of $\mathrm{C} 1$ (high) for foreign graduates of Lviv Polytechnic National University, so they clearly follow the structure of certification work on Standardized Requirements: reading (30 min, 4 tasks), writing (75 min, 2 tasks), listening (15 min, 3 tasks), speaking (15 min, 2 tasks). Evaluation - for each correct answer there will be one point.

The article emphasizes that the standardized requirements for the levels of proficiency in Ukrainian as a foreign language are a strategic document for educational policy, language policy and international policy of Ukraine, which strengthens the prestige of the Ukrainian language in the world.
\end{abstract}

Постановка проблеми. «Інтеграція України в міжнародний культурний та інформаційний простір, відкритість українського суспільства, можливість його громадян вільно подорожувати, брати участь у міжнародних мистецьких конкурсах, фестивалях, спортивних турнірах, а також збільшення кількості туристів 3-за кордону посилили зацікавленість до вивчення української мови як іноземної», - такими словами розпочинається посібник «Стандартизовані вимоги: рівні володіння українською мовою як іноземною А1-С2. Зразки сертифікаційних завдань, 2020» [6, с. 4]. Робота над стандартом і розроблення сертифіка- ційних іспитів для іноземців, які хочуть розуміти, знати українську мову, а також отримати сертифікат, - це титанічна праця кожного, хто долучиться до цієї справи. Звичайно ж, кожен університет України, який має іноземців, уже пропонує напрацьовані зразки проведення внутрішнього іспиту й матеріали для оцінювання рівнів володіння мовою, але це все потрібно звести до єдиного правильного стандарту.

Мета статті - встановити, відповідно до Стандартизованих вимог, рівень володіння українською мовою як іноземною у Національному університеті «Львівська політехніка» після проведення 
Кваліфікаційного іспиту з української мови у студентів-іноземців четвертого курсу. У статті з'ясовується, як правильно скомпонувати різні види завдань щодо видів мовленнєвої діяльності, щоб оцінити рівень володіння мовою кожного претендента, чітко виділити час для кожного завдання та скласти таблицю оцінювання. Також необхідно дослідити, підібрати та адаптувати науково-популярні тексти відповідно до рівня $\mathrm{C} 1$ для проведення Кваліфікаційного іспиту з української мови як іноземної, скласти зрозумілі та цікаві завдання, які розкриють потенціал кожного студента.

Виклад основного матеріалу дослідження. Національний університет «Львівська політехніка» приймає на навчання кожного року приблизно 40-50 студентів із різних країн світу, таких як Еквадор, Конго, Нігерія, Ангола, Марокко, Йорданія, Єгипет, Палестина, Америка, Канада, Росія, Польща, Молдова та інші. Усі вони живуть в україномовному середовищі та навчаються українською мовою впродовж трьох із половиною років на різних спеціальностях. На четвертому курсі вони складають Кваліфікаційний іспит 3 української мови, який оцінюється відповідно до норм університету. Але оцінювання не передбачає визначення рівнів загального володіння українською мовою та вручення сертифікатів. Студенти прекрасно розмовляють, пишуть і спілкуються. Все залежить, звичайно, від кожного індивідуально, та ми орієнтуємося на рівень С1 (Стандартизовані вимоги УМІ визначають такі рівні володіння українською мовою як іноземною: Початковий (A1). Базовий (A2). Рубіжний (B1). Середній (В2). Високий (C1). Вільне володіння (C2)) [6, с. 7]. Щоб перевірити знання кожного, викладачі кафедри іноземної мови Секції мовної підготовки іноземних студентів розробили зразки тестувань для проведення іспиту на 4-му курсі 3 української мови. Відповідно до усталених методів навчання будь-якої іноземної мови, ми намагалися дотриматися певної послідовності й у процесі навчання, і у часі проведення іспитів. Весь час написання роботи (2,5 години) чітко розділений на чотири частини, далі йде перерва і п'ята частина $(10$ хв) - представлення власної презентації: 1. Слухання - відео- чи аудіоролик із науково-популярної тематики і 15 завдань (трьох типів). Загальний час -15 хв. 2. Граматичні тести (15 хв). 3. Письмо (есе, 200-250 слів). Загальний час -1 год. 4. Читання текстів і 15 завдань (чотирьох типів). Загальний час -30 хв. Заповнення бланку відповідей. 5. Говоріння на вибрану тему, 5 хв. Презентація за спеціальністю, 10 хв. Щоби правильно оцінити знання студента, необхідно дотримуватися усіх норм і вимог стандарту щодо загального переліку умінь кожного мовного виду роботи. Не рекомендується давати студентам тек- сти $з$ їхньої спеціальності чи для слухання, чи для читання. Теми повинні бути довільні, тексти науково-популярні.

Вимоги до С1 (Високий). Визначає активне володіння українською мовою як іноземною та можливість компетентного спілкування в україномовному (у т. ч. професійному) середовищі 3 осмисленим та легким використанням усіх мовленнєвих умінь та виражальних засобів (у т. ч. галузевої термінології, професіоналізмів, найуживаніших ідіом).

1. СЛУХАННЯ. 1.1. Загальний перелік умінь. Претендент розуміс довготривале мовлення, навіть якщо воно не досить чітко структуроване або коли його зв'язність виражена не прямо; головні і другорядні думки, озвучені нормативною вимовою у повідомленнях складної структури, якщо це стосується кола його особистих або навчальних зацікавлень; досить складне пояснення нового матеріалу під час навчальної лекції, якщо нова тема продовжує і доповнює попередню; зміст дискусії та позицію учасників щодо невідомої для нього теми; деталі оголошень, виголошених у громадських місцях; більшість радіоi телепрограм, новин, документальних і художніх фільмів загальної тематики; значення слова і фрази залежно від тональності мовлення; зміст і мету практично всіх жанрів усного мовлення; стилістично марковані тексти, які містять розмовні вислови та ідіоми; швидке мовлення у природних умовах повсякденного життя в недосконалих акустичних обставинах (шум, фоновий шум, наприклад у кафе або на вулиці). Тексти повинні бути на актуальну (конкретну чи абстрактну) тему, у тому числі стосуватися й технічних (спеціалізованих) питань та фахового спілкування. Обсяг тексту: до 800 слів. Кількість нових слів: до $7 \%$. Темп мовлення: 120 слів на хвилину [6, с. 87].

2.ЧИТАННЯ. 2.1. Загальний перелік умінь. Претендент має розуміти загальний зміст і деталі великих за обсягом і складних за структурою неадаптованих текстів різних стилів і жанрів у межах професійних і особистих зацікавлень; висловлену непрямо інформацію (натяки, іронію, жарти); науково-популярні тексти із різних сфер; значення i функції найбільш уживаних ідіоматичних і канцелярських зворотів; ставлення автора до описуваних подій, виражене прямо чи приховано. Претендент може переглянути великий текст із метою 3'ясувати, чи наявна в ньому потрібна інформація, потрібні деталі. Претендент може знайти у тексті більшість інформації стосовно однієї чи кількох деталей. Претендент має швидко ідентифікувати загальний зміст тексту, повідомлення за заголовком чи підзаголовком (якщо вони інформативні й однозначні). Претендент може виділити в тексті засоби міжфразового зв'язку і зрозуміти їхню 
функцію. Обсяг тексту: 800-1000 слів. Кількість нових слів: до $5-7 \%$ [6, с. 89].

3. ПИСЬМО. 3.1. Загальний перелік умінь. Претендент уміє: висловлюватись на письмі у формі чіткого, добре структурованого тексту, використовуючи складні синтаксичні конструкції; вибирати стиль писемного повідомлення відповідно до особистісних характеристик відомого чи уявного читача; писати детальні тексти (обсягом не менше 200 слів) на теми 3 кола загальних та особистих зацікавлень, засвідчуючи контрольоване й усвідомлене вживання граматичних структур та засобів міжфразового зв'язку; вибирати мовні виражальні засоби відповідно до мети та стилю тексту; написати загальний огляд змісту книги, фільму, вистави чи певної події, учасником або очевидцем якої він/вона був/була, зокрема використовуючи лексичні та графічні засоби передавання прямої (невласне прямої, непрямої) мови на письмі; написати доповідь, твір-роздум, аналітичну довідку з елементами опису та роздуму на тему 3 кола зацікавлень, відповідно до складеного плану, вибірково користуючись словником; конспектувати прочитану інформації у вигляді структурованого тексту, з виділенням пунктів і підпунктів, формуванням переліків, 3 виділенням головного й другорядного; писати приватні чи офіційні листи на складні теми, виділяючи те, що він/вона вважає найважливішим; писати складні листи, доповіді й статті, представляючи проблему (предмет розгляду) за допомогою ефективної логічної структури, що дозволяє адресатові виділити й запам'ятати найважливіші пункти; писати огляди та анотації до текстів із професійної чи загальнокультурної сфери; уживати на письмі засоби іномовлення та перефразування, щоби приховати прогалини словника та граматики [6, с. 91].

4. ГОВОРІННЯ. 4.1. Загальний перелік умінь.

А. Монологічне мовлення. Претендент уміє: висловлюватися на загальні чи абстрактні теми, а також на теми, що пов'язані $з$ його/їі професією і зацікавленнями, вибудовуючи інтонаційно-тематично завершені фрагменти тексту (співвідносні 3 абзацами); чітко і докладно описувати складні реалії і явища, завершуючи мовлення логічним висновком; прокоментувати переглянутий фільм, прочитану книжку чи статтю, висловлюючи власні враження і ставлення; доречно цитувати чужі думки, додаючи їх до власного висловлювання; аргументовано висловлювати власні погляди стосовно актуальних соціальних чи політичних питань; досить невимушено виступати перед аудиторією із заздалегідь підготовленою промовою; формулювати гіпотези для пошуку рішень імовірних проблем; застосовувати стратегії коригування і полегшення вислову (заміну невідомих слів описом, оминання складних місць) непомітно для співрозмовників.

Б. Діалогічне мовлення. Претендент уміє: висловлюватись вільно і спонтанно, майже без зусиль на загальні чи абстрактні теми (навіть якщо вони йому/їй не досить відомі); гнучко й ефективно користуватися мовою в соціумі, у тому числі образно та для вираження емоцій і жартів; дискутувати навіть на абстрактні чи невідомі теми, переконливо аргументуючи свою позицію, відповідаючи на запитання та коментарі, швидко, спонтанно й адекватно реагуючи на складну аргументацію; вільно брати участь в інтерв'ю стосовно професійної діяльності чи загальних питань (як інтерв'юер або респондент) [6, с. 93].

Відповідно до структурованого опису всіх видів мовленнєвої діяльності, пропонуємо зразок білету 3 кваліфікаційного іспиту 3 української мови як іноземної для студентів-іноземців 4-х курсів технічних вишів. Тексти і завдання будуть не повні, частинами, і міститимуть чітко описані вимоги до кожного виду завдань.

Кваліфікаційний іспит 3 УКРАЇНСЬКОЇ МОВИ (як іноземної)

БІЛЕТ № 1_ПИСЬМОВА ЧАСТИНА. СЛУХАННЯ. 15 хвилин.

Ви подивитеся відеофрагмент з ҮоиТиве-каналу програми IQ епеrgy «До найвищої енергоефективності», iqenegy@org.ua [7], в якому йдеться про альтернативні джерела енергії. Під час перегляду відео виконайте завдання 1-15. Будьте уважні: відповіді на завдання з'являються в такій самій послідовності, щзо й інформація відеофрагменту. Перегляньте завдання 1-8. Тоді подивіться перший уривок відео і виконайте ияі завдання.

Досі ми говорили про те, як економити енергію. Але ви знаєте, що ії можна отримувати майже безкоштовно - завдяки сучасним винаходам. Теплові насоси - це пристрої, що беруть енергію 3 повітря, грунту, грунтових вод і використовують iii для опалення чи підігріву води. Для роботи їм потрібно трохи електрики - близько 1 кіловата... [stop на 2:05].

Завдання 1-8. Заповніть пропуски - вставте ОДНЕ слово І/АБО число.

Теплові насоси - це пристрої, що беруть 1 3 повітря, грунту, грунтових вод. Натомість вони вироблять 4-2 кіловати тепла. За цим паливом - джерелом енергії - теплові насоси бувають 3

Перегляньте завдання 9-12. Тоді подивіться наступний уривок відео і виконайте иі завдання. Виберіть ОДИН правильний варіант відповіді лiтеру $A, B$ чи $C$.

Хто $з$ нас не бачив літніх душів на дачах? Темна діжка, що гріє воду від сонця. Це і $є$ прототип 
сонячного колектора. Еволюція зробила величезний крок уперед. Сучасні колектори здатні підігрівати воду навіть узимку. Бувають вони двох видів... [stop на 3:06]

9. Темна діжка, що гріє воду від сонця - це ... сонячного колектора.

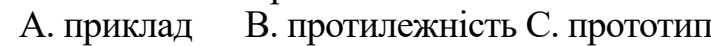

10. Сучасні сонячні колектори бувають ...

А. двох видів. В. трьох типів. С. зимові і літні.

Перегляньте завдання 13-15. Тоді подивіться наступний уривок відео і виконайте ичі завдання. Поставте літеру П, якщо інформація з відео правильна, або $H$ - якщзо інформачія неправильна або іï нема.

До будь-якого колектора потрібно встановити бак-акумулятор із товстими стінками. У ньому зберігатиметься підігріта вода, котру можна використати пізніше, приміром уночі чи за хмарної погоди. Хочете знати, які з новацій підійдуть вам? Оберіть свій тип житла.

13. У баку-акумуляторі з товстими стінками буде зберігатися підігріта вода.

14. Сонячні колектори, грунтової й повітряні теплові насоси не можна використовувати у приватному будинку.

15. Повітряний насос i сонячний колектор можна встановити лише у звичайній квартирі.

ЧИТАННЯ. 30 хвилин. Прочитайте текст $i$ виконайте завдання 1-15.

Морська сіль - витвір сонця, води і вітру. Випарювання солі природним способом на Атлантичному узбережжі Франції почалося ще приблизно в 3-му сторіччі н. е. Але справжній розквіт цього ремесла припадає на кінець середньовіччя. Ріст кількості населення в тодішній Європі привів до збільшення попиту на сіль, адже за їі допомогою зберігали м'ясо і рибу. До берегів Бретані припливали кораблі з усієї Північної Європи: тут купували величезну кількість солі для консервації. Протягом багатьох сторіч спосіб видобутку солі на Атлантичному узбережжі практично не змінився. Як збирають сіль? ... [8].

Завдання 1-5. Чи відповідають иі твердження інформачії в тексті? Позначте: дження правильне (відповідає інформащії з тексту), $\boldsymbol{H}$ - якщзо твердження неправильне (суперечить інформачії з тексту) або якщзо така інформачія відсутня.

1. На узбережжі Атлантики сіль також збирають у механізований спосіб.

2. Французькі кухарі високо цінують «соляне борошно» - флер-де-сель.

3. Коли літо спекотне, можна зібрати дуже багато морської солі...

Завдання 6-8. Про які ТРИ факти згадано в тексті? Виберіть літери $A-G$ (послідовність не має значення).
А. Добування золота на Атлантичному узбережжі Франції.

В. Випарювання морської солі в соляних басейнах.

С. Сучасна торгівля Франції з країнами Північної Європи.

D. Різні способи добування солі у Франції.

E. Залежність промислу добування морської солі від погодних умов.

F. Порівняння видобутку морської солі в різні роки.

G. Особливості національної французької кухні.

Завдання 9-12. Виберіть ОДИН правильний варіант відповіді - літеру А, В, C або D.

9. У кліматі Середземного моря можна збирати понад 1,5 млн тонн солі ...

А. за сезон. В. щоквартально. С. кожного року. D. щомісяця.

10. Мікроскопічні водорості, які розмножуються в ропі, роблять іï ...

А. різкою. В. рожевою. С. різноманітною. D. ароматною.

ЛЕКСИКО-ГРАМАТИЧНІ ТЕСТИ. 5 Хвилин. Виберіть ОДИН правильний варіант відповіді лiтеру $A, B, C, D$ або $E$.

1. У котрому рядку є слово, протилежне за значенням до слова найновіший?

А. останній; В. найстаріший; С. несвіжий; D. перший.

2. Котрі з наведених іменників уживаються лише у формі однини?

1. Свято. 2. Черешня. 3. Телебачення. 4. Данія. 5. Споруда. 6. Напрям. 7. Радість. 8. Смуга. 9. Кальцій. 10. Винахід.

A. $1,3,4,6,7,9$. B. $1,2,4,7,8,9$. C. $2,5,6,8,10$. D. $3,4,7,9$. E. 3, 4, 7, 8, 10.

3. У котрому рядку правильно утворено всі прикметники?

А. архітектура - архітектурний, географія географічний, держава - державний;

В. економіка - економічний, Європа - європський, історія - історичний;

С. культура - культурний, центр - центральний, місто - містський;

D. музика - музичний, тоді - тодійний, проблема - проблемовий.

4. У котрому рядку правильно поєднано іменники з числівниками?

А. чотири функцій, дві дівчати; В. п'ятнадцять студентів, двоє друзів;

С. дві рук, сто вісімдесят дні; D. вісім завдань, сорок три автобуса.

5. Котрі з наведених дієслів у 3-й особі множини мають закінчення «ать(-ять)»?

1. Зв’язати. 2. Тримати. 3. Бажати. 4. Говорити. 5. Летіти. 6. Збирати. 7. Сідати. 8. Працювати. 9. Відповідати. 10. Зеленіти. 
A. $1,4,5,6,7,8,10$. B. $2,4,5,6,7,8,9$. C. $4,5,7,9$. D. 4, 5. Е. жодне.

ПИСЬМО. 1 година. Напишіть 200-250 слів. Розкрийте тему:

1. Що, на вашу думку, означає бути героєм? Хто є героєм у вашому житті?

2. Щораз більше людей сьогодні роблять покупки онлайн. Які є плюси і мінуси покупок онлайн для покупців і для продавців?

Кваліфікаційний іспит 3 УКРАЇНСЬКОЇ МОВИ (як іноземноі)

БІЛЕТ № 1_УСНА ЧАСТИНА_ГОВОРІННЯ НА ВИБРАНУ ТЕМУ. 5 Хвилин.

1. Яке значення, на вашу думку, має самостійна робота студента під час навчання? 2. Хто з сучасних видатних людей $\epsilon$ чи може бути для вас прикладом у житті?

ПРЕЗЕНТАЦІЯ ЗА СПЕЦІАЛЬНІСТЮ.

10 хвилин. Оцінювання: максимальна кількість балів за усну частину - 40 (говоріння на вибрану тему - 20, презентація - 20); максимальна кількість балів за письмову частину - 60 (слухання 15 , лексико-граматичні тести - 10 , читання -15 , письмо - 20); максимальна кількість балів за іспит загалом - $100(60+40)$.

Висновки. Проведення контролю за стандартизованими вимогами - це дотримання норм, які містять перелік загальноприйнятих зразків та правил щодо комунікативних умінь і відповідають змісту володіння українською мовою як іноземною певного рівня, певного ступеня якості умінь і навичок. Тому сподіваємося, що впровадження Стандартизованих вимог до рівнів володіння УМІ (А1-С2), які є сукупністю норм і положень, що окреслюють вимоги Української держави до рівня володіння українською мовою з боку осіб, для яких українська мова не $є$ рідною (першою), відбудеться якнайшвидше та підсилить престиж української мови у світі.

\section{ЛITEPATУРA}

1. Бахтіярова Х., Лукашевич С., Майданюк І., Сегень М., Пєтухов С. Українська мова: Практичний курс для іноземців. Тернопіль : Укрмедкнига, 1999. 296 с.

2. Вінницька В., Плющ Н. Українська мова. Практичний курс граматики для студентів-іноземців. Київ : Факт, 1997. 244 с.

3. Зайченко Н., Воробйова С. Практичний курс української мови для іноземців: усне мовлення. Київ : Академвидав, 2004. 324 с.

4. Лиса Н., Кривоус М., Тишковець М. Українська мова як іноземна: основи граматики в таблицях та вправах : навч. посіб. Тернопіль : Економічна думка, 2011. 312 с.

5. Навчальні плани та програми (довузівська підготовка іноземних громадян) / уклад. : Л.Г. Новицька, О.Ф. Гудзенко, М.І. Дудка та ін., ч. 1. Київ : ІВЦ: Видавництво «Політехніка», 2003. 56 с.

6. Стандартизовані вимоги : рівні володіння українською мовою як іноземною А1-С1. Зразки сертифікаційних завдань : посібник / Данута Мазурик, Леся Антонів, Олена Синчак, Галина Бойко. Київ : Фірма «IНКОС», 2020. $186 \mathrm{c}$.

7. https://www.youtube.com/watch?v=D_gA-oCgZPk

8. https://www.jw.org/uk/\%D0\%B1\%D1\%96\%

\section{REFERENCES}

1. Bakhtiiarova Kh., Lukashevych S., Maidaniuk I., Sehen M., Pietukhov S. (1999) Ukrainska mova: Praktychnyi kurs dlia inozemtsiv [Ukrainian language: Practical course for foreigners]. Ternopil : Ukrmedknyha. $296 \mathrm{~s}$.

2. Vinnytska V., Pliushch N. (1997) Ukrainska mova. Praktychnyi kurs hramatyky dlia studentiv-inozemtsiv [Ukrainian language. Practical grammar course for foreign students]. Kyiv : Fakt. $244 \mathrm{~s}$.

3. Zaichenko N., Vorobiova S. (2004) Praktychnyi kurs ukrainskoi movy dlia inozemtsiv: usne movlennia [Practical course of the Ukrainian language for foreigners: oral speech]. Akademvydav. Kyiv. 324 s.

4. Lysa N., Kryvous M., Tyshkovets M. (2011) Ukrainska mova yak inozemna: osnovy hramatyky v tablytsiakh ta vpravakh [Ukrainian as a foreign language: basics of grammar in tables and exercises]: Navch. posib. Ternopil : Ekonomichna dumka. $312 \mathrm{~s}$.

5. Navchalni plany ta prohramy (dovuzivska pidhotovka inozemnykh hromadian) (2003) [Curricula and programs (pre-university training of foreign citizens)] / uklad. : L.H. Novytska, O.F. Hudzenko, M.I. Dudka ta in., ch. 1. Kyiv : IVTs: Vydavnytstvo «Politekhnika». $56 \mathrm{~s}$.

6. Standartyzovani vymohy: rivni volodinnia ukrainskoiu movoiu yak inozemnoiu A1-S1. Zrazky sertyfikatsiinykh zavdan: posibnyk (2020) [Standardized requirements: levels of proficiency in Ukrainian as a foreign language A1-C1. Samples of certification tasks: a guide] / Danuta Mazuryk, Lesia Antoniv, Olena Synchak, Halyna Boiko. Kyiv : Firma «INKOS». 186 s.

7. https://www.youtube.com/watch?v=D_gA-oCgZPk

8. https://www.jw.org/uk/\%D0\%B1\%D1\%96\% 